\title{
UJI RESISTENSI BAKTERI ESCHERICHIA COLI YANG DIISOLASI DARI PLAK GIGI TERHADAP MERKURI DAN ANTIBIOTIK KLORAMFENIKOL
}

\author{
${ }^{1}$ Ronal Dian \\ ${ }^{2}$ Fatimawali \\ ${ }^{2}$ Fona Budiarso \\ ${ }^{1}$ Kandidat Skripsi Fakultas Kedokteran Universitas Sam Ratulangi Manado \\ ${ }^{2}$ Bagian Kimia Fakultas Kedokteran Universitas Sam Ratulangi Manado \\ Email: r.dian11_103@yahoo.co.id
}

\begin{abstract}
Mercury is a liquid element at room temperature. Some main effects of mercury are dysfunctional of brain, kidneys and lungs, tremor, anxiety or nervous, insomnia, fetal growth restriction, and liver damage in pregnancy. Dental plaque is a soft material that attach on tooth's surface, dental filling, or calculus. Antibiotic is a chemical substance that has the ability to inhibit the growth and kill microorganisms. Chloramphenicol is a broad-spectrum antibiotic that useful for treatment of a number of bacterial infections and anaerobic bacteria. The research using descriptive method. Subject of the research was mercury resistence Escherichia coliwhich isolated from dental plaque with dental filling and grew at broth Luria Bertani (LB) and solid LB. The result of observation on bacteria after incubated at $37^{\circ} \mathrm{C}$ for 24 hours showed that at $\mathrm{HgCl}_{2}$, with available dilution, found bacteria at dental plaque with higher amounts of growth at $10 \rho \rho m$ concentration, intermediate amount of growth at $20 \rho \rho m$ concentration, and less amount of growth at $40 \rho \rho \mathrm{m}$ concentration. As the result of observation on Escherichia coli after 24 hours of incubation, researcher found that the inhibition zone diameter of Eschericia coli for 30 $\mu$ g chloramphenicol was $20 \mathrm{~mm}(>12 \mathrm{~mm})$ during first, second, and third treatment and included in sensitive category.

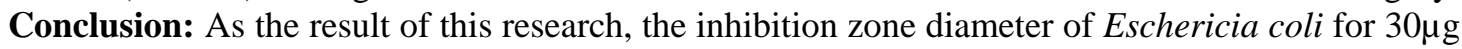
chloramphenicol was $20 \mathrm{~mm}(>12 \mathrm{~mm})$ during first, second, and third treatments and included in sensitive category.
\end{abstract}

Keywords: mercury, dental plaque, chloramphenicol, Eschericia coli.

\begin{abstract}
Abstrak: Merkuri adalah suatu unsur berbentuk cair keparatan dalam suhu kamar. Resiko utama merkuri adalah tidak berfungsinya otak, ginjal, tremor, rasa gelisah atau gugup, insomnia, gangguan fungsi paru-paru, memperlambat pertumbuhan janin, kerusakan liver pada kehamilan. Plak gigi adalah deposit lunak yang melekat pada permukaan gigi, tumpatan, maupun kalkulus. Antibiotik adalah zat kimia yang mempunyai kemampuan untuk menghambat pertumbuhan dan membunuh mikroorganisme. Kloramfenikol adalah antibiotik spektrum luas yang efektif terhadap beberapa jenis bakteri dan bakteri anaerob. Penelitian adalah metode deskriptif eksploratif. Sampel yang diambil dalam penelitian adalah bakteri Escherichia coli resistensi merkuri yang diisolasi dari plak gigi dengan tumpatan amalgam dan tumbuh pada media Luria Bertani (LB) broth dan media LB padat.Pengamatan setelah bakteri diinkubasi pada suhu $37^{\circ} \mathrm{C}$ selama 24 jam didapatkan hasil bahwa pada $\mathrm{HgCl}_{2}$ dengan pengeceran yang ada, di dapatkan bakteri isolat yang diidentifikasi dari

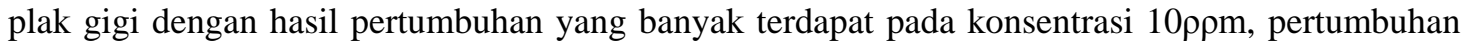
sedang terdapat pada konsentrasi $20 \rho \rho \mathrm{m}$, dan pertumbuhan sedikit terdapat pada konsentrasi

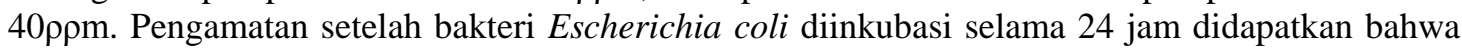
diameter zona hambat Escherichia coli terhadap antibiotik kloramfenikol 30 $\mu$ g pada pengulangan pemberian I, II, dan III sebesar 20mm (>12mm) dan termasuk dalam kategori sensitif. Simpulan: Hasil uji yang tekah dilakukan didapatkan bahwa diameter zona hambat Escherichia coli terhadap

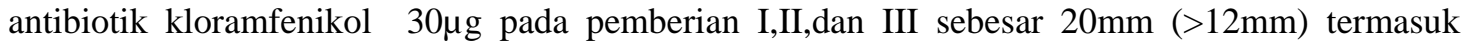
dalam kategori sensitif.
\end{abstract}

Kata kunci: merkuri, plak gigi, kloramfenikol, bakteri Echerichia coli 
Merkuri merupakan suatu unsure berbentuk cair keperatan dalam suhu kamar. Merkuri membentuk berbagai persenyawaan baik anorganik maupun organik. Jika merkuri dikonsumsi atau meresap dalam tubuh manusia bahayanya cukup besar. Gejalagejalanya seperti tidak berfungsinya otak, ginjal, tremor, rasa gelisah atau gugup, insomnia, gangguan fungsi paru-paru, memperlambat pertumbuhan janin, hingga kerusakan liver pada kehamilan. ${ }^{1,2}$ Plak gigi adalah deposit lunak yang melekat pada permukaan gigi, tumpalan, maupun kalkulus. $^{3}$

Antibiotik adalah zat kimia yang dihasilkan oleh mikroorganisme yang mempunyai kemampuan dalam larutan encer, untuk menghambat pertumbuhan dan membunuh mikroorganisme. Antibiotik yang relatif non-toksik terhadap penjamunya digunakan sebagai agen kemoterapeutik dalam pengobatan penyakit infeksi pada manusia. ${ }^{4}$ Salah satu jenis antibiotik adalah kloramfenikol. Kloramfenikol adalah antibiotik spektrum luas yang efektif terhadap beberapa jenis bakteri dan kuman anaerob. ${ }^{5,6}$

Berdasarkan pemaparan yang ada maka penulis tertarik untuk melakukan penelitian tentang uji resistensi bakteri Escherichia coli yang diisolasi dari plak gigi terhadap merkuri dan antibiotik kloramfenikol.

\section{METODE PENELITIAN}

Penelitian ini menggunakan metode deskriptif eksploratif, dimana penelitian ini dilakukan pada bulan Oktober 2014 Desember 2014. Sampel yang telah ada di bawah ke Laboratorium Mikrobiologi Farmasi, Program Studi Farmasi, Fakultas MIPA Universitas Sam Ratulangi untuk dilakukan uji terhadap kadar resistensi merkuri dan uji resistensi antibiotik kloramfenikol. Populasi dalam penelitian ini adalah semua bakteri yang tumbuh pada plak gigi pasien dengan tumpatan amalgam. Sedangkan Sampel yang diambil dalam penelitian ini adalah bakteri Escherichia coli resistensi merkuri yang diisolasi dari plak gigi dengan tumpatan amalgam dan tumbuh pada media Luria
Bertani (LB) broth dan media LB padat.

Penelitian ini dilakukan melalui beberapa tahap, yaitu tahap isolasi bakteri resistensi merkuri diamana bertujuan untuk mengisolasi bakteri-bakteri yang ada pada sampel plak gigi. Prosedur kerjanya, koloni Escherichia coli ditumbuhkan pada media Luria Bertani (LB) yang sudah mengandung merkuri setelah perhitungan total koloni, kemudian dipindahkan pada media agar miring dengan menggunakan jarum ose sebagai kultur sediaan (antibiotik) dan selanjutnya disimpan pada suhu $4^{0} \mathrm{C}$. Dilakukan seleksi kultur bakteri, seleksi ini dilakukan dengan cara inokulasi kultur bakteri Escherichia coli dalam media Luria Bertani (LB) yang mengandung $\mathrm{HgCl}_{2}$ dalam beberapa kadar yang berbeda yaitu $10 \rho \rho \mathrm{m}(10 \mathrm{mg} / \mathrm{l}) ; 20 \rho \rho \mathrm{m}(20 \mathrm{mg} / \mathrm{l})$; $40 \rho \rho \mathrm{m}(40 \mathrm{mg} / \mathrm{l}) ; 80 \rho \rho \mathrm{m}$ (80 mg/l) dan diinkubasi pada suhu $37^{\circ} \mathrm{C}$ selama 24 jam. Selanjutnya diamati jumlah koloni yang tumbuh.

Selanjutnya uji resistensi antibiotik, yaitu tahap uji resistensi bakteri yang sudah resistensi merkuri dimana bertujuan untuk menetukan zona daya hambat bakteri resistensi merkuri terhadap antibiotik kloramfenikol. Prosedur kerjanya, Uji resistensi antibiotik dilakukan dengan menginokulasi bakteri resistensi merkuri pada media Luria Bertani (LB) broth padat. Kertas disk antibiotik dengan konsentrasi standar antibiotik diletakkan menggunakan pinset steril pada permukaan media Luria Bertani (LB) broth padat yang sudah diinokulasikan bakteri. Kertas disk antibiotik diaturjaraknya agar tidak terlalu rapat lalu diinkubasi selama 24 jam, suhu $37^{\circ} \mathrm{C}$. Diamati perubahan yang terjadi dan diukur zona bening dengan menggunakan jangka sorong. Setelah serangkaian uji resistensi merkuri dan uji resistensi antibiotik, maka data ditabulasi dalam tabel kemudian dibandingkan hasilnya.

\section{HASIL PENELITIAN}

\section{Hasil Isolasi Bakteri Resistensi Merkuri}

Bakteri yang telah ada dibawah ke Laboratorium Mikrobiologi Farmasi, Program Studi Farmasi, Fakultas MIPA 
Universitas Sam Ratulangi untuk dilakukan uji terhadap kadar resistensi merkuri yaitu terhadap $\mathrm{HgCl}_{2}$ dengan pengenceran $10 \rho \rho m, 20 \rho \rho m, 40 \rho \rho m$, dan $80 \rho \rho m$.

Dari hasil isolasi bakteri resistensi merkuri setelah diinkubasi pada suhu $37^{\circ} \mathrm{C}$ selama 24 jam didapatkan hasil bahwa pada $\mathrm{HgCl}_{2}$ dengan pengeceran yang ada, di dapatkan bakteri isolat yang diidentifikasi dari plak gigi dengan hasil pertumbuhan yang banyak terdapat pada konsentrasi
$10 \rho \rho m$, pertumbuhan sedang terdapat pada konsentrasi $20 \rho \rho m$, pertumbuhan sedikit terdapat pada konsentrasi $40 \rho \rho m$, dan tidak ada pertumbuhan pada konsentrasi $80 \rho \rho m$. Oleh sebab itu penulis memutuskan untuk mengambil isolat bakteri yang pertumbuhannya banyak pada konsentrasi $10 \rho \rho m$ dan selanjutnya diadakan pemeriksaan identifikasi bakteri dan pemeriksaan uji resistensi antibiotik kloramfenikol.

\section{Uji Resistensi Merkuri}

\begin{tabular}{|c|c|c|}
\hline Media Luria & Pertumbuhan & Keterangan \\
\hline
\end{tabular}

\begin{tabular}{cccc}
\hline $10 \rho \rho \mathrm{m}$ & + & Pertumbuhan banyak & Merah \\
\hline $20 \rho \rho \mathrm{m}$ & + & Pertumbuhan sedang & Merah-Jernih \\
\hline $40 \rho \rho \mathrm{m}$ & + & Pertumbuhan sedikit & Merah-Jernih \\
\hline $80 \rho \rho \mathrm{m}$ & - & Tidak ada & Jernih \\
\hline
\end{tabular}

\section{Hasil Uji Resistensi Antibiotik Kloramfenikol}

Bakteri yang telah didapatkan dari uji resistensi merkuri yaitu Escherichia coli kemudian dilakukan uji resistensi terhadap

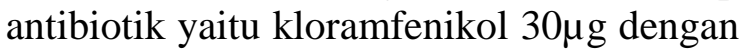
pengulangan sebanyak tiga kali.

Hasil pengamatan yang telah dilakukan di Laboratorium Mikrobiologi Farmasi, Program Studi Farmasi, Fakultas
MIPA Universitas Sam Ratulangi, setelah bakteri Escherichia coli diinkubasi selama 24 jam dalam median yang mengandung antibiotik didapatkan bahwa diameter zona hambat Escherichia coli terhadap antibiotik kloramfenikol $30 \mu \mathrm{g}$ sebesar $20 \mathrm{~mm}$ $(>12 \mathrm{~mm})$ dan termasuk dalam kategori sensitif, dan pada pengulangan pemberian antibiotik kloramfenikol 30 $\mu$ g kedua dan ketiga didapatkan hasil yang sama.

Uji Resistensi Antibiotik Kloramfenikol

\begin{tabular}{ccc}
\hline $\begin{array}{c}\text { Pengulangan } \\
\text { pemberian } \\
\text { antibiotik } \\
\text { kloramfenikol } \\
30 \mu \mathrm{g}\end{array}$ & $\begin{array}{c}\text { Zona } \\
\text { hambat }\end{array}$ & Keterangan \\
\hline I & $20 \mathrm{~mm}$ & $\begin{array}{c}\text { Sensitif } \\
(>12 \mathrm{~mm})\end{array}$ \\
\hline II & $20 \mathrm{~mm}$ & $\begin{array}{c}\text { Sensitif } \\
(>12 \mathrm{~mm})\end{array}$ \\
\hline III & $20 \mathrm{~mm}$ & $\begin{array}{c}\text { Sensitif } \\
(>12 \mathrm{~mm})\end{array}$ \\
\hline
\end{tabular}




\section{BAHASAN}

\section{Isolasi Bakteri Resistensi Merkuri}

Berdasarkan hasil peneltian yang dilakukan dengan mengambil sampel plak gigi pasien dengan tumpalan amalgam, maka ditemukan adanya bakteri resistensi merkuri pada sampel tersebut dimana hasil uji resistensi merkuri menunjukan semua isolat tumbuh pada pemberian $\mathrm{HgCl}_{2}$ dan diinkubasi selama 24 jam.

Setelah dilakukan uji resistensi bakteri terhadap merkuri, tahap selanjutnya yang dilakukan adalah uji resistensi bakteri terhadap antibiotik kloramfenikol.

\section{Uji Resistensi Antibiotik Kloramfenikol}

Antibiotik adalah zat kimia yang dihasilkan oleh suatu mikroba yang mempunyai khasiat antimikroba. Mekanisme kerja antibiotik antara lain adalah menghambat sintesis dinding sel, merusak permeabilitas membran sel, menghambat sintesis RNA (proses transkripsi), menghambat sintesis protein (proses translasi), menghambat replikasi DNA. ${ }^{7}$ Kloramfenikol adalah antibiotik yang mempunyai aktivitas bakteriostatik dan pada dosis tinggi bersifat bakterisidal. Aktifitasnya menghambat sintesis protein dengan jalan mengikat ribosom yang merupakan langkah penting dalam pembentukan ikatan peptida. ${ }^{8}$

Prinsip dari percobaan ini adalah penghambatan terhadap pertumbuhan mikroorganisme, yaitu zona hambatan akan terlihat sebagai daerah jernih di sekitar daerah yang mengandung zat antibakteri. Diameter zona hambatan pertumbuhan bakteri menunjukkan sensitivitas bakteri terhadap zat antibakteri. Selanjutnya dikatakan bahwa semakin lebar diameter zona hambatan yang terbentuk bakteri tersebut semakin sensitif.

Berdasarkan hasil pengamatan setelah sampel diinkubasi selama 24 jam, diperoleh hasil bahwa pada cakram yang diberikan antibiotik kloramfenikol, terdapat zona hambat yang ditandai dengan daerah sekitar antibiotik berwarna bening. Diameter zona hambat antibiotik kloramfenikol adalah 20mm (>12mm) dan termasuk kategori sensitif.

Antibiotik kloramfenikol akan melekat pada subunit 50s ribosom bakteri sehingga menghalangi enzim Peptidil-tranferase. Enzim inilah yang melaksanakan 3 langka dengan membentuk ikatan peptida antara asam amino baru yang masih melekat pada tRNA-nya, dan asam amino terakhir peptida yang sedang berkembang. Hal ini menyebabkan sintesis protein terhenti seketika. Bila tidak terjadi perubahan struktur purin oleh bakteri maka sensitifitasnya tidak akan berkurang. Purin merupakan tempat masuknya antibiotik agar antibiotik dapat bekerja pada dinding sitenya. Struktur purin yang tetap pada dinding sel bakteri menyebabkan bakteri. Escherichiacoli masih sensitif terhadap antibiotik kloramfenikol. ${ }^{9,10}$

\section{SIMPULAN DAN SARAN}

Bakteri Escherichia coli pada plak gigi yang telah diisolasi resisten merkuri telah terbukti resistensi terhadap merkuri pada konsentrasi 40ppm. Pada konstrasi 10 ppm, 20 ppm dan 40 ppm bakteri masih bisa bertumbuh sedangkan 80 ppm bakteri sudah tidak bertumbuh atau sudah mati.

Berdasarkan uji resistensi bakteri Escherichia coli terhadap antibiotik kloramfenikol 30 $\mu \mathrm{g}$ yang ada didalam cakram didapatkan hasil bahwa pada pemberian yang pertama diameter zona hambat Escherichia coli terhadap antibiotik kloramfenikol $30 \mu \mathrm{g}$ sebesar $20 \mathrm{~mm}$ $(>12 \mathrm{~mm})$ dan termasuk dalam kategori sensitif, dan pada pengulangan pemberian antibiotik kloramfenikol kedua dan ketiga didapatkan hasil yang sama.

Untuk para praktisi di bidang kedokteran gigi, sebaiknnya perlu dipertimbangkan kembali pemilihan bahan dasar tumpatan gigi yang bebas merkuri, dan juga pertimbangan dalam pemberian antibiotik. Penelitian-penelitian selanjutnya harus dilakukan secara berkelompok dan menggunakan antibiotik yang sama dengan perlakuan yang berbeda. 


\section{UCAPAN TERIMA KASIH}

Ucapan terima kasih pada Nurmiati, S.si, Dr. dr. Billy J. Kepel, MMedSc dan Dr. Altje F. Manampiring, Mkes sebagai penguji skripsi, dan semua pihak yang dengan baik secara langsung telah menumbuhkan ide dan gagasan dalam pemikiran penulis.

\section{DAFTAR PUSTAKA}

1. Sitohang, Y. Karya tulis ilmiah sarjana. Identifikasi Isolat Bakteri resistensi Merkuri pada Media Kultur Awal yang Mengandung Merkuri di Kelurahan Ketang Baru, Kota Manado. Fakultas Kedokteran Universitas Sam Ratulangi. 2011:11-13.

2. Subandri, S. Kajian Beban Pencemaran Merkuri Terhadap Air Sungai Menyuke dan Gangguan Kesehatan pada Penambang Sebagai Akibat Penambangan Emas Tanpa Izin (PETI) di Kecamatan Menyuke Kabupaten Landak Kalimantan Barat, Proposal Tesis Universitas Diponegoro. 2008.

3. Setyawan S. Adi SM. Saluhiyah Z. Wijanrko B. Istiarti T. Ginanjar P. studi intervensi pemakaian larutan disclosing oleh murid sendiri dalam mengontrol plak gigi. Semarang: Universitas Diponegoro;1999
4. W.A. Newman Dorland. Kamus Kedokteran Dorland. Edisi 31. Jakarta: Penerbit Buku Kedokteran EGC; 2010.p: 115.

5. Gerald, K Mc.evoy(2005). American Hospital Formulary Service, American Society of Health System Pharmacist, United States of America.

6. Kunardi, L dan Setiabudy, R.(1995). Antimikroba GolonganTetrasiklin dan Kloramfenikol, dalam Farmakologi dan Terapi. Edisi Keempat. Bagian Farmakologi dan Terapi FKUI. Jakarta. p.615,657.

7. Immanudin $\mathbf{H}$. Pola Pertumbuhan dan Toksisitas Bakteri Resisten $\mathrm{HgCl}_{2}$. Jurnal EKOSAINS. 2010;2(1).

8. Anomin (1980). A Diagnostic Manual of Veterinary Clinical Bacteriology and Mycology, Unesco/Cida, Regional Training Course in Veterinery Dagnostic Mycobiologi Deradeniya,p. 72.

9. Goodman and Gilman, 2007, Dasar Farmakologi Terapi, Edisi 10, diterjemahkan oleh Amalia, Penerbit Buku Kedokteran EGC, Jakarta.

10. Volk dan Wheeler. 1988. Mikrobiologi Dasar. Edisi Kelima. Jilid I. Penerbit Erlangga. Jakarta. 